ROCZNIKI NAUK PRAWNYCH

Tom XXX, numer $4-2020$

DOI: https://doi.org/10.18290/rnp20304-8

JACEK SROKOSZ

\title{
MERITOCRATIC JUSTIFICATION IN RULEMAKING AND ITS CRITICISM BASED ON THE EXAMPLE OF AMERICAN REGULATORY AGENCIES
}

\section{INTRODUCTION}

Experts and expertise are frequently invoked in contemporary public discourse and considered to be playing a special role in social life. British sociologists, Anthony Giddens and Ulrich Beck, describe modern societies as based on expert systems ${ }^{1}$. Due to the complexity of contemporary people's lives, they are not able to make all decisions on their own. Therefore, they expect that experts, being the ones who possess knowledge, will find the best solution to their problems. In this sense, expert knowledge is gradually supplanting other existing grounds for making decisions, that is moral arguments or arguments referring to political will. The above-mentioned processes result in attempts to shift the expertise-based narrative from a descriptive to a normative level and thus create a socio-political system, meritocracy. Social life, hitherto dominated by political will, has become another area to remain under the influence of experts. The paper aims to show how meritocratic justification is used in the rulemaking of American independent regulatory agencies (IRA). The first part of the article will be devoted to the idea of meritocracy and the resultant project of reshaping the social and political life. Then, government agencies will be outlined as expert institutions. Finally, the narrative invoking meritocratic justification and its critique will be discussed. The paper's research

JACEK SROKOSZ PhD - Assistant Professor, Department of Science of the State and Law, Institute of Law, Faculty of Law and Administration, University of Opole, ul. Katowicka 87a, 45-040 Opole; e-mail: jsrokosz@uni.opole.pl; https://orcid.org/0000-0002-7587-6483.

${ }^{1}$ A. GIDDENS, Życie w społeczeństwie posttradycyjnym, [in:] Modernizacja refleksyjna. Polityka, tradycja i estetyka $w$ porządku spotecznym nowoczesności, eds. U. Beck, A. Giddens, S. Lash, Warszawa: PWN 2009, pp. 82-83; U. BECK, Ponowne odkrycie polityki: przyczynek do teorii modernizacji refleksyjnej, [in:] Ibidem, pp. 16-17. 
thesis is that the role of meritocratic justification is not only to legitimize but also mask political decisions made by government agencies.

\section{THE CONCEPT AND POSTULATES OF MERITOCRACY}

The concept of meritocracy is quite frequently used in contemporary social science. It most often appears in sociological discourse, especially with reference to education and equal opportunities ${ }^{2}$. Nowadays it is also more and more often used in political science. When it comes to legal discourse, it is not referred to that frequently, although it does appear in the context of the legitimization of lawyers' power and position, especially judges, in modern society. In those types of discourse, meritocracy is assigned many definitions and meanings ${ }^{3}$. However, it seems that it can be generally defined as a certain demand for remodelling social and political life towards a system in which the position of an individual in the social hierarchy depends on objectively verifiable and confirmed competencies. Numerous attempts have been made in scientific discourse to approach meritocracy as an objective and non-ideological methodology of action. Those in turn resulted in endeavours to create objective systems of promotion based on competencies to be used by public institutions, private law entities and the entire state (the Chinese system of imperial administration, starting from the Qin dynasty) ${ }^{4}$. In my view, meritocracy is above all a certain normative postulate deriving from and based on a certain system of values, and therefore it should be considered an ideological term. The main postulate of meritocracy understood as an ideology is the assumption that one's place in the social structure should depend on objective personal qualifications, and the power over certain areas of social life should be entrusted to persons who possess objective and professional knowledge of a given area.

\footnotetext{
${ }^{2}$ The problem of meritocratic education and inequality is discussed by: Ch. HAYES, Twilight of the Elites: America after Meritocracy, New York: Broadway Books 2012; K. LAMPERT, Meritocratic Education and Social Worthlessness, London: Palgrave-Macmillan 2012; W. DERESIEWICZ, Excellent Sheep: The Miseducation of the American Elite and the Way to a Meaningful Life, New York: Free Press 2014; J. LiTTER, Against Meritocracy. Culture, power and myths of mobility, London-New York: Routledge 2018.

${ }^{3}$ On the meaning of meritocracy see Chang-Hee KIM, Yong-Beom CHOI, How Meritocracy is Defined Today?: Contemporary Aspects of Meritocracy, "Economics and Sociology" vol. 10, 2017, No. 1, pp. 112-121.

${ }^{4}$ Meritocracy and Economic Inequality, eds. K.J. Arrow, S. Bowles, S.N. Durlauf, New Jersey: Princeton University Press 2000.
} 
The term meritocracy is a blend of two words: the Latin "mereō", meaning merit, and the Greek suffix "kratos", meaning power or rule. It was introduced into public discourse by the British sociologist Michael Young in the dystopia “The Rise of Meritocracy. 1870-2033" published in 1958 . It is a pessimistic vision of the British social and political system's transformation from a class one with domination of aristocracy towards a meritocratic one. In the latter, power was to be exercised by a new class selected according to objective specialist criteria. That change was to be motivated by the need to ensure effective and efficient management of the economy and the state through better use of human resources. It was to be achieved through developing a system of social advancement based not on one's ancestry or wealth but one's objectively proven merits, including intellectual potential, personal talents and work. Therefore, in this system, social advancement was to be possible for anyone who had a talent and made efforts to develop it creatively. As a result, a new professional elite was anticipated to emerge, with the highest qualifications to optimally manage the state and social life.

Although Young's vision of the society's transformation towards a fairer one seems positive at first, its final result would not be that positive according the author himself. The power over social life would be taken over by a new egoistic class, a professional one but without proper moral qualifications to exercise it. Thanks to more advantageous cultural capital offered to their children, the new elite would begin to isolate themselves from others just as aristocracy did before. Hence the myth of creating a just system for exchanging elites would not come true. Being isolated from other social groups, the new elite would only concentrate on its own interests, identifying them as the interests of the whole society. This would be accompanied by contempt for lower classes considered objectively inferior by the elite.

Although at first glance Young's meritocracy seems to be only a description of an effective way of selecting qualified elites, it is undoubtedly a normative project of ethical nature. The effects of that ideology would be twofold, for the individual and for the society.

In its individual dimension, that ideology refers to justice ${ }^{6}$. It promises to build a new social structure where positions are filled according to the criteria of one of the visions of justice - to each according to their merits ${ }^{7}$. Therefore,

\footnotetext{
${ }^{5}$ M. Young, The Rise of Meritocracy: 1870-2033, Harmondworth: Pinguin 1958.

${ }^{6}$ See: T. Mulligan, Justice and Meritocratic State, London: Routledge 2019.

${ }^{7}$ A. Giddens, Socjologia, Warszawa: PWN 2004, p. 725; H. DOMAŃSKI, Struktura społeczna, wydanie nowe, Vol. I, Warszawa: Wydawnictwo Naukowe Scholar 2007, pp. 28-29.
} 
the place of individuals in the social hierarchy depends on themselves and their own actions, not on subjective qualities or circumstances beyond their control, such as e.g. the fact of being born in a wealthy family. The implementation of the new ideology was expected to give birth to a merit-based system of social advancement accessible to every gifted and diligent person ${ }^{8}$. These concepts have been playing a major role in the contemporary visions of liberal societies, in particular in the United States". They reflect the visions of the "American Dream" which serves as the basis for the official narrative of the US liberal system that everyone, through their own actions, works on their own success or failure and is fully responsible for their social status ${ }^{10}$.

When it comes to its social dimension, meritocracy refers to a vision of better social life management, where power is entrusted to the most competent individuals. Obviously, such a vision was not Young's intellectual creation, as it had already been an element of political and social thought in ancient times. It can be seen in the Platonic social utopia, where power is exercised by the wisest philosophers - kings. It is also present in Confucius's philosophy, where rulers are selected not on the basis of their ancestry but qualifications. In the political system of Imperial China, the implementation of Confucianism principles in this regard entailed creating a clerical hierarchy selected on the basis of examinations, not one's background ${ }^{11}$. The revival of meritocracy in modern social philosophy was a result of the combination of two factors: the philosophy of enlightenment, which assumed that it was possible to learn about the world and all its rules, and the victory of capitalism with its shape of social life, which resulted in attempts to identify the most effective way of managing the society as if it was a factory. Varieties of meritocratic ideas could be found not only in the utopian projects of Henri de Saint Simon's "governments of engineers"12 but also in the practical concepts of technocracy

${ }^{8}$ G. Marshall, A. Swift, Meritocratic Equality of Opportunity: Economic Efficiency, Social Justice, or Both?, "Policy Studies" 1997, No. 18, pp. 35-48.

${ }^{9}$ See: J.F. KeTt, Merit: The History of a Founding Ideal From the American Revolution to the Twenty-First Century, New York: Cornell University Press 2012.

${ }^{10}$ R. Sealy, Changing Perceptions of Meritocracy in Senior Women's Careers, "Gender in Management: An International Journal" Vol. 25, 2010, No. 3, pp. 184-197; L. A. Alvarado, Dispelling the Meritocracy Myth: Lessons for Higher Education and Student Affairs Educators, "The Vermont Connection" Vol. 31, 2010, pp. 10-20.

${ }^{11}$ Broadly: D. Bell, The China Model. Political Meritocracy and the Limits of Democracy, New Jersey: Princeton University Press 2015.

${ }^{12}$ F. Manuel, The New World of Henri Saint-Simon, Cambridge, Mass., 1956; Gh. Ionescu, The Political Thought of Saint-Simon, Oxford: Oxford University Press 1976. 
or managerialism by authors such as Thorstein Veblen and, more contemporarily, Daniel Bell or John Kenneth Galbright ${ }^{13}$.

Although contemporary meritocratic concepts are not attempting to develop great social visions such as those utopian concepts, their predominance in public discourse is beyond doubt. They have become part of contemporary social rationality, a tempting opportunity to have a government composed of specialists, which can ensure effective and efficient management of social life ${ }^{14}$. Together with the idea of individuality and one's responsibility for their own life, meritocracy has perfectly fitted into the liberal narrative, equipping it with philosophical and ethical grounds. The Enlightenment belief that the rules governing the world could be learnt and understood led to the assumption that persons who possessed more knowledge and competencies than others had a privileged position.

The social life management based on the principles of meritocracy was to entail marginalization or even complete repudiation of politicalness considered by Chantal Mouffe and Ernesto Laclau a primary and irremovable antagonism of social groups ${ }^{15}$. According to the two authors, the basis for and the driving force of social life is an irremovable conflict between social groups over a limited range of goods and a privileged hegemonic position in the structure of society. With its fair and equal for everyone rules for arranging social relations, meritocracy was a promising way to overcome this antagonism. The cost of such an action was to be a limitation of political, that is the freedom to articulate and fight for one's group interests, which could take any form, and entrustment of social life management to persons with appropriate qualifications. Although it was not possible to completely eliminate political will from a democratic

${ }^{13}$ J. KURCZEWSKA, Technokraci i ich świat spoteczny, Warszawa: Wydawnictwo ISiF PAN 1997; T. VeBLen, The Engeneers and The Price System, [in:] What Veblen Thaught: Selections from the Writings of Thorstein Veblen, New York: Martino Fine Books 2012; D. BeLL, On Meritoracy and Equality, "National Affairs" Fall 1972; J. BuRnhAM, The Managerial Revolution: What is Happening in the World, New York: John Day Co. 1941; J.K. GalbRAITH, The New Industrial State, Boston: Houghton Mifflin Harcourt 1967; D. Bell, The Coming of Post-industrial Society: A Venture In Social Forecasting, New York: Basic Books 1973.

${ }^{14}$ K. JASIECKI, Zasady merytokratyczne w polityce państwa - wzloty i upadki, „Studia z Polityki Publicznej" Vol. 11, 2016, No. 3, pp. 9-40.

${ }^{15}$ Ch. Moufre, Polityczność, Warszawa: Wydawnictwo Krytyki Politycznej 2008, p. 24. The same meaning: J. ŁaKOMY, Polityczność (teorii) wyktadni prawa. Perspektywa neopragmatyzmu Stanleya Fisha, „Archiwum Filozofii Prawa i Filozofii Społecznej” 2018, No. 3(18), pp. 24-25. There are also others meaning of Political see: A. SulikowsKi, R. MaŃKO, J. ŁaKOMY, Polityczność prawa i ogólnej refleksji nad prawem: zagadnienia ogólne, „Archiwum Filozofii Prawa i Filozofii Społecznej” 2018, No. 3(18), p. 5; R. MAŃKO, W stronę krytycznej filozofii orzekania. Polityczność, etyka, legitymizacja, Łódź: Wydawnictwo Uniwersytetu Łódzkiego 2018, pp. 147-151. 
system, it was necessary to limit its impact as far as possible and to give the professional factor a decisive voice (where possible). Experts were to gradually replace politicians in the process of shaping the rules of social life $\mathrm{e}^{16}$.

\section{GOVERNMENT AGENCIES AS AN EXPERT FACTOR}

The idea of meritocratic social life management presented above quickly found its reflection in the American public discourse. It is the USA where attempts have been made to implement meritocracy ideas ${ }^{17}$. One of the areas particularly influenced by that ideology is rulemaking. An example of an expert entity regulating selected areas of social life are Independent Regulatory Agencies (IRAs).

IRAs are government agencies ${ }^{18}$. They are autonomous public law entities performing public administration tasks, though they are often outside the structures of public administration. The agencies' autonomy is guaranteed by the fact that they have their own budgets and ability to shape political relations with the Congress, the president, and interest groups that may give them political support ${ }^{19}$. The most common ones are the so-called executive agencies. They are responsible for performing certain public administration tasks through implementing regulations of other entities. In simple terms, they carry out managerial activities. They are usually, to a greater or lesser extent, part of state administration

\footnotetext{
${ }^{16}$ This process was depicted by Mark Bovens and Anchrit Wille, who claim that contemporary western states in fact became "Diploma Democracy" - ruled by those with the highest formal qualifications. See: M. Bovens, A. Wille, Diploma Democracy: The Rise of Political Meritocracy, Oxford: Oxford University Press 2018.

${ }^{17}$ D. LIPSEY, The Meretriciousness of Meritocracy, "The Political Quarterly" Vol. 85, 2014, No. 1 , pp. 37-42.

${ }^{18}$ On types of government agencies in US see: M.J. BREGER, G.J. EDLES, Independent Agencies in The United States: Law, Structure and Politics, Oxford: Oxford University Press 2015. European government agencies was depicted by: A. KREHER, Agencies in the European Community - a step towards administrative integration in Europe, „Journal of European Public Policy” 1997, No. 4, pp. 225-245; E.M. BuSUIOC, European agencies: Law and practices of accountability, Oxford: Oxford University Press 2013; E. CHITI, European Agencies' Rulemaking: Powers, Procedures and Assessment, "European Law Journal" Vol. 19, 2013, No. 1, pp. 93-110; T. Christensen, P. LÆGReID, Autonomy and regulation: Coping with agencies in the modern state, Cheltenham: Edward Elgar Pub 2006; M. GROENLEER, The autonomy of European Union agencies: A comparative study of institutional development, Delft: Eburon Uitgeverij BV 2009; B. RitTBERGER, A. WONKA, Agency Governance in the EU, London: Routledge 2013. Polish government agencies was depicted by: P. BIEŚ-SROKOSZ, Agencje rzqdowe jako szczególne podmioty administracji publicznej, Warszawa: C.K. Beck 2020.

${ }^{19}$ G.B. Peters, The United States of America, [in:] K. Verhoest, S. VAn Thiel, G. BoucKaert, P. LÆgerid, Government Agencies. Practice and Lessons from 30 Countries, New York: Palgrave Macmillan 2012, p. 69 and nexts.
} 
structure and most often report to the president. Apart from executive and regulatory agencies, there are other entities described as agencies, with different legal status and managerial tasks.

The formation and functioning of agencies in the US should be treated as a kind of desire to professionalize and depoliticize certain areas of public life ${ }^{20}$. It was a desire to create a different model of administration than the European one. Americans were not willing to duplicate the European model of bureaucracy which they blamed for the unlimited power of officials. On the one hand, this reluctance was a result of their lack of trust in authorities and willingness to limit their (authorities') competence and influence on the lives of citizens, and on the other, concerns that those in power could turn into tyrants if their structures were excessively developed. Undoubtedly, there was also a fear that administration bodies could become politicized through being involved in the activities of politicians willing to gain and maintain power. In addition, along with the rapid economic development and industrialization, especially after the Civil War, it became necessary for the state to take a more active role not only in regulating and supervising economic processes but also in activities related to social issues or public security. This meant that the administration had to be expanded but in a way acceptable to the citizens.

The then emerging agency-like model of administration seemed to fulfil the hopes placed in it and dispel the fears of state apparatus politicization by excluding certain areas controlled by administration from the political struggle and leaving their management to professionals ${ }^{21}$. The aim was, above all, to limit the "war trophy" practices of victorious political parties who filled the biggest possible number of public administration positions with their own people regardless of their competencies. Replacing party appointees with people possessing appropriate skills as well as giving them considerable independence and autonomy from the world of politics was to guarantee a higher quality of services provided and more effective methods of solving social problems ${ }^{22}$. This independence was to be guaranteed by adequately long terms of office of agencies' presidents and

${ }^{20}$ P. SABATIER, Social Movements and Regulatory Agencies: Toward a More Adequate - and Less Pessimistic - Theory of "Clientele Capture". "Policy Sciences" Vol. 6, 1975, p. 302.

${ }^{21}$ M. MAGGETTI, Legitimacy and Accountability of Independent Regulatory Agencies: A Critical Review, "Living Reviews in Democracy" 2010, No. 2, p. 2; N. Devins, D. LewIS, Not-So Independent Agencies: Party Polarization and the Limits of Institutional Design, "Boston University Law Review" Vol. 88, 2008, p. 463.

${ }^{22}$ D.J. GIFFORD, The New Deal Regulatory Model: A History of Criticisms and Refinements, "Minnesota Law Review" Vol. 68, 1983, pp. 306-307. According to Grant Gilmore thesis that attitude was typical for "Age of Faith" in evolution of American administrative law. G. GILMORE, The Ages of American Law, New Haven-London: Yale University Press 1977. 
members of agencies' managing committees, which made it more difficult to dismiss them and made it difficult for the president or the Congress to exercise direct supervision over their activities ${ }^{23}$. This mechanism resembles the one applied to judges at the federal level. Although their selection is not free from certain political elements, the moment the judges take their office they are supposed to be independent of other authorities' influence and public opinion. Obviously, this analogy to the judiciary cannot be too far-reaching, as they have a much greater scope of power and a more important position within the system than agencies. Nevertheless, it should be noted that, as in the case of judges, the position of agencies within the system is not determined with the use of a democratic justification but a meritocratic one.

References to the latter are particularly visible in the legislation of regulatory agencies. The agencies' legislative competence has been an object of debate for many years, as the Constitution does not provide for legislative entities other than the Congress ${ }^{24}$. However, it is quite common for the Congress to delegate some of its legislative power to an agency the moment it is created. At the same time, the Congress lays down the scope of the delegated legislative competence and the catalogue of matters to be dealt with by the agency. From their very beginning, regulatory agencies were formed to regulate the issues related to economy and trade. The first regulatory agency, Interstate Commerce Commission, was established in 1887 (and ceased to operate in 1995) ${ }^{25}$. Later, similar agencies were also established to regulate the mechanisms of the free market and trade, but since the 1960s and 1970s agencies have been also being established to regulate social, health and some of political matters ${ }^{26}$.

As Dominique Custos points out, the formation of regulatory agencies was inspired by a vision of expert regulations derived from and based on scientific knowledge, which was to reconcile the economic interests of individuals with the interests of the society as a whole ${ }^{27}$. The American common law system guaranteed individuals a wide autonomy, a large scope of property rights and a wide freedom to conclude contracts, but the exercise of these rights had to

\footnotetext{
${ }^{23}$ Broadly: F. Gilardi, M. MAGGetTI, The independence of regulatory authorities, [in:] Handbook on the politics of regulation, ed. D. Levi-Faur, Cheltenham: Edward Elgar 2011.

${ }^{24}$ Broadly on delegation legislative power by Congress to agencies, see: T.W. MerriLl, K.T. WATTS, Agency Rules with the Force of Law: The Original Convention, "Harvard Law Review" Vol. 116, 2002, No. 2, pp. 467-592.

${ }^{25}$ R.D. STONE, The Interstate Commerce Commission and the railroad industry: a history of regulatory policy, New York: Praeger 1991.

${ }^{26}$ G.P. Miller, Independent Agencies, "The Supreme Court Review" 1986, pp. 41-97.

${ }^{27}$ D. Custos, The Rulemaking Power of Independent Regulatory Agencies, "The American Journal of Comparative Law" Vol. 54, 2006, pp. 615-639.
} 
be reconciled with the interests of the state and the entire community. This reconciliatory role could not be fulfilled solely by the courts ${ }^{28}$. They set the limits of individual freedom and the scope of administration's interference in that right, but always did it in reaction to certain phenomena the effect of which was a conflict brought before court. Certain active entities were needed to regulate selected social issues. Entrusting these competencies to agencies and not to the Congress or state congresses was motivated by the professionalism and better efficiency of the former ${ }^{29}$. The expert knowledge of agencies' employees was to guarantee that their decisions were of a higher substantive quality and, at the same time, made faster thanks to not having to carry out time-consuming and costly legislative processes ${ }^{30}$.

Obviously, the implementation of those ideas entailed certain political costs. The autonomy granted to the agencies had to result in limiting the scope of their responsibility before the Congress, the president, and the public opinion ${ }^{31}$. Although it posed a risk of losing control over the agencies' activity, the meritocratic narrative described that situation a "lesser evil". The first and most popular argument was the agencies' purpose, that is to effectively perform the entrusted tasks. Their broad autonomy enabled them to take effective and less costly actions, which would not be possible if they (agencies) were to be more dependent on political bodies and controlled by the public opinion ${ }^{32}$. The standard legislative process was too long, too formalized and, above all, too costly. Simultaneously, regulations created during that process had to cater for the interests of pressure groups and the expectations of voters instead of being objectively the best method of solving a certain social issue ${ }^{33}$. With time, the

\footnotetext{
${ }^{28}$ Broadly about the role of courts in protection of civil rights in US see: M.D. WILLIAMS, Judicial Review: The Guardian of Civil Liberties and Civil Rights, " George Mason University Civil Rights Law Journal" 1990, No. 1; R. O'ConNell, Guardians of the Constitution: Unconstitutional Constitutional Norms, "Journal of Civil Liberties" 1999, No. 4.

${ }^{29}$ T.O. MCGARITY, The Courts and the Ossification of Rulemaking: A Response to Professor Seidenfeld, "Texas Law Review" Vol. 75, 1996-1997, pp. 525-526.

${ }^{30}$ T.O. MCGARITY, Some Thoughts on "Deossifying” the Rulemaking Process, "Duke Law Review" Vol. 41, 1992, p. 1385.

${ }^{31}$ M.J. BREGER, G.J. EDLES, Established by practice: the theory and operation of Independent Federal Agencies», “Administrative Law Review” Vol. 52, 2000, No. 4, p.1198.

${ }^{32}$ Stephen Johnson claim that: "Over the past few decades, Congress, the courts, and the executive branch have layered so many significant procedural requirements on notice and comment rulemaking that most academics and policymakers agree that the process has become ossified and inefficient". S. JoHnSON, Junking the "Junk Science" Law: Reforming the Information Quality Act, "Adminstrative Law Review” Vol. 58, 2006, p. 61.

${ }^{33}$ J.L. MASHAw, Reasoned Administration and Democratic Legitimacy: How Administrative Law Supports Democratic Government, Cambridge: Cambridge University Press 2018, p. 97.
} 
agencies' over-politicization and their decreasing autonomy led to lower efficiency and increased costs, which was irrational as the costs incurred exceeded the profits obtained ${ }^{34}$. In addition, being specialist entities that drew from sci entific methodology, the agencies' legislation could be of higher quality then the one produced as a result of a standard legislative procedure ${ }^{35}$. They were free from the political pressure exerted by the above-mentioned interest groups, and at the same time, they did not have their own interests to be pursued by means of their own legislative activity.

The agencies were pictured as defenders of the rights and interests of the citizens to the extent that they had been allowed to. Hence any attempts to limit their regulatory power must hinder the effectiveness of that protection ${ }^{36}$. It should be noted that the above argument is as significant as the demands that the judiciary be independent and depoliticized. As I have mentioned before, both the institutions use the meritocratic narrative to justify their special position and independence from political processes. The core of that narrative is paternalism, i.e. it is the expert that knows what is better for the citizen. Hence pure political will present in the state and the federal legislature should be restricted in favour of expert rulemaking.

\section{LEGISLATIVE MERITOCRACY AS A CURTAIN DRAWN OVER REAL PROCESSES - A CRITIQUE OF EXPERT RULEMAKING}

The meritocratic justification for the rulemaking activity of regulatory agencies presented above is more and more often criticized, not only by the so-called populist politicians but also representatives of the world of science. First of all, one should remember about the American distrust of any kind of authority, especially the executive one and its subordinate units ${ }^{37}$. Agencies are no exception ${ }^{38}$, which is confirmed by the obligations related to rulemaking imposed by the Congress also on regulatory agencies in Administration Procedure

\footnotetext{
${ }^{34}$ R.A. KAGAN, Adversarial Legalism: The American Way Of Law, Cambridge-London: Harvard University Press 2001, pp. 196-201.

${ }^{35}$ See: Ch. DeMuth, Can the Administrative State Be Tamed?, "Journal of Legal Analysis" Vol. 8, 2016, No. 1, pp. 121-190.

${ }^{36}$ T.O. MCGARITY, The Courts, pp. 530-533.

${ }^{37}$ D. RubinsteIn ReISs, Account Me In: Agencies in Quest of Accountability, ,Journal of Law and Policy" Vol. 19, 2011, No. 2, p. 620.

${ }^{38}$ E.C. Hargrove, J.C. Glidewell, Impossible Jobs In Public Management, Lawrence: University Press of Kansas 1990, pp. 5-8.
} 
Act of $1946^{39}$. Pursuant to the APA, as well as other acts, during the informal rulemaking process agencies are obliged to announce their intention to regulate along with detailed information and justification, gather opinions of potentially interested entities and interest groups, prepare a draft regulation and make it available to the public, and finally, properly announce the regulation and its detailed reasons ${ }^{40}$. As one can see, the requirements have been imposed to guarantee the transparency of the rulemaking process, as well as to ensure that all interested parties can participate in that process and express their views. It is also possible to legislate by means of a formal process resembling court proceedings, but it is only required in matters arousing controversy, which is why it is used much less frequently than the informal one ${ }^{41}$.

Although the provisions of the Act oblige agencies to remain transparent and make sure that the interested can participate in the rulemaking process, the results of recent studies show that many agencies ignore that obligation or comply with it only selectively ${ }^{42}$. According to the critics, this results in an insignificant influence of public opinion on the shape of regulations while they are being made, and since those regulations are universally binding, this translates into a limitation of civil rights. Although the regulations passed by agencies may be repealed by a legislative veto of the Congress or a court ruling, these are follow-up control activities which usually require a lot of effort and take a long time ${ }^{43}$. Therefore, the regulatory autonomy of agencies leads to a gradual extension of their competencies without democratic legitimacy, and thus results in that citizens have no real influence on the shape of regulations that may affect them ${ }^{44}$.

In addition, it is pointed out that the two arguments supporting the independence of agencies mentioned above, i.e. their political neutrality and lack of own

\footnotetext{
${ }^{39}$ The Administrative Procedure Act (APA), Pub.L. 79-404, 60 Stat. 237.

${ }^{40}$ D. Custos, The Rulemaking Power, pp. 624-625. Broadly: J. LubBers, Guide to Federal Agency Rulemaking, Chicago: American Bar Association 2006.

${ }^{41}$ D. Custos, The Rulemaking Power, p. 627.

${ }^{42}$ C. RAso, Agency Avoidance of Rulemaking Procedures, "Administrative Law Review" Vol. 67, 2015, No. 1, pp. 101-167.

${ }^{43}$ D.A. MARTIN, The Legislative Veto and the Responsible Exercise of Congressional Power, "Virginia Law Review" Vol. 68, 1982, No. 2, pp. 253-302. Although usage of legislative veto was limited by Supreme Court in 1983 in case INS v. Chadha it is still important tool for limiting legislative competence of agencies. L. FISHER, Legislative Veto: Invalidated it survives, "Law and Contemporary Problems" Vol. 56, 1993, pp. 273-292.

${ }^{44}$ The issue of democratic legitimacy of IRA's is discussed by: M. SCHOLTEN, Democratic Input Legitimacy of IRAs:Proposing an Assessment Framework. "Utrecht Law Review" Vol. 11, 2015, No. 2, pp. 64-77; R.T. Bull, Making The Administrative State "Safe For Democracy": A Theoretical And Practical Analysis Of Citizen Participation In Agency Decisionmaking, "Administrative Law Review" Vol. 65, 2013, No. 3, pp. 611-664.
} 
interests, are myths. As for the former, agencies cannot be apolitical in the sense adopted by Mouffe, because they participate in the distribution of goods and thus pursue someone's interests at the expense of someone else's. Therefore, even provisions that seem to be purely technical in nature can be a mechanism for pursuing specific interests ${ }^{45}$. Agencies are also not free from politics understood as the activity of specific groups aimed at gaining and maintaining power, i.e. party rivalry ${ }^{46}$. This is because pressure groups or lobbyists exert influence on agencies just as they do during legislative processes in the Congress ${ }^{47}$. In that case such pressures must by disclosed by virtue of law and the process is transparent. It does not hold, however, for agencies, which leaves much more space for potential abuse ${ }^{48}$. For those interested in having specific regulations passed, the agency method of legislation, especially the informal procedure, is a much easier and cheaper way to push favourable legal solutions than the ordinary legislative process. Finally, agencies as entities having a certain position in the system of power have their own interests, and the lack of transparency or responsibility makes it easier for them to pursue those interests, especially in socially controversial matters ${ }^{49}$.

The arguments criticizing the meritocratic narrative in the rulemaking of regulatory agencies point to the double role of the argument of professionalism.

First of all, it serves to legitimize the decisions taken by pointing to the professionalism of the regulatory entity, which is to guarantee that objectively the best solution of a given social issue has been adopted. A cognitively privileged expert, based on his scientific knowledge, is to solve social problems better than politicians and the legislative process. Thus the rules of scientific discourse and the resultant rationality of actions are to replace the decisions taken within the political discourse. This virtually means shifting the burden of decision making from citizens to experts, which leads to a gradual reduction of the democratic factor and raises the risk of forming a new kind of oligarchy,

${ }^{45}$ D. KenNedy, The Political Stakes in "Merely Technical" Issues of Contract Law, "European Review of Private Law" Vol. 10, 2001, No. 1, pp. 7-28.

${ }^{46}$ On the issue of influence of interests groups on regulation of agencies see: C.M. KERwIN, S.R. FurLong, Rulemaking: How Government Agencies Write Law and Make Policy, fifth edition, Washington: CQ Press 2018.

${ }^{47}$ The issue of influence on agencies by industry was discussed by P.J. Quirk, Industry influence in Federal Regulatory Agencies, New Jersey: Princeton University Press 2014.

${ }^{48}$ According to theory of Marver Bernstein agency always fall under influence of their "clients" and finally are going rather to secure "client's" interest, then aimed social goals. see: M. BERNSTEIN, Regulating Business by Independent Commissions, New Jersey: Princeton University Press 2015.

${ }^{49}$ S. CRoley, Regulation and Public Interests: The Possibility of Good Regulatory Government, New Jersey: Princeton University Press 2008, pp. 18-22. 
an expert one. The relation between the elites and the rest of the society is therefore transformed into a paternal one. As D. Beetham points out, meritocratic legitimacy and the resultant paternalism make the elites lose touch with the rest of the society and identify their own interests as the interests of all the citizens $^{50}$. In fact, the meritocratic narrative is a tool used to justify the interests and position of the social elite, just as Young described in his pessimistic vision.

Second of all, the meritocratic narrative serves as a certain screen for real political processes, hiding them under the cover of expert activity, i.e. objective and non-political. As indicated before, it is not possible to remove politics from social life, but it is possible to create a narrative that masks it. Nevertheless, sooner or later this narrative begins to be contested and eventually rejected as protecting the interests of the privileged elite. For some researchers, the so-called populist movements are exactly the social response rejecting the expert narrative and its underlying social assumptions ${ }^{51}$. Obviously, the masking function of meritocratic justification in the legislative process may also work at the level of current political rivarly for gaining and maintaining power. Here it becomes a banner covering the real balance and play of forces and interest groups struggling to pass legislative solutions that are most favourable to them. Expert rulemaking is therefore just as entangled in politics as the ordinary legislative process, but the advantage of the latter is that it reveals the essence of that process, whereas the former conceals it and carefully masks it.

\section{CONCLUSIONS}

The above discussion of the rulemaking activities performed by American regulatory agencies allows to highlight the problems liberal democracy is to face, as this type of democracy draws from meritocratic ideas. Meritocracy has become permanent part of modern public discourse and it would be difficult to reject it completely. It is perceived as an important part of contemporary

\footnotetext{
${ }^{50}$ D. BeEtham, The Legitimation of Power, New York: Palgrave Macmillan 1991, p. 73.

${ }^{51}$ H. BAng, D. MARsh, Populism: a major threat to democracy?, "Policy Studies" Vol. 39, 2018, No. 3, p. 340; R. MARKowski, Populism and Nationalism in CEE: Two of a Perfect Pair?, [in:] When Populism meet Nationalism. Reflections of Parties in Power, ed. A. Martinelli, Milan: Ledizioni Ledi Publishing 2018, passim. General sight on phenomenon of populism see: J.-W. MÜLLER, What is Populism?, Philadelphia: University of Pennsylvania Press 2016; P. TAGGarT, Populism, Buckingham: Open University Press 2000; P. BlokKer, Populist Constitutionalism, [in:] Routledge Handbook of Global Populism, ed. C. de la Torre, London: Routledge 2018; Y. Mouk, The People vs. Democracy. Why Our Freedom in in Danger and How to Save it?, Cambridge: Harvard University Press 2018.
} 
social rationality, hence in order to reject it one would have to redefine the latter. Nevertheless, putting the principles of meritocracy on a pedestal with regard to specific areas of social life at the expense of other systems of assessment that do not refer to professionalism can bring about negative social and political phenomena. Therefore, although undoubtedly significant, the professional factor cannot be regarded as the only, indisputable and final in resolving social and political issues due to its seemingly neutral and merely masking nature. In the long run, the meritocratic narrative expands the scope of power entrusted to experts at the expense of democratic rules, which has indeed been noticed and become part of the debate over the practices of American regulatory agencies. A number of authors point out that citizens should have a greater influence on the shape of regulations adopted by expert entities, regulations that in a significant way affect their lives. This does not absolutely mean that expert rulemaking should be rejected, but a certain balance between the expert and the civic factors in the functioning of social life should be ensured.

\section{BIBLIOGRAPHY}

Alvarado Lorriz Anne: Dispelling the Meritocracy Myth: Lessons for Higher Education and Student Affairs Educators, "The Vermont Connection" Vol. 31, 2010, pp. 10-20.

BANG Henrik, MARsh David: Populism: a major threat to democracy?, "Policy Studies" Vol. 39, 2018, No. 3, pp. 352-363.

BeEtham David: The Legitimation of Power, New York: Palgrave Macmillan 1991.

BELL Daniel: On Meritoracy and Equality, "National Affairs” Fall 1972.

Bell Daniel: The China Model. Political Meritocracy and the Limits of Democracy, New Jersey: Princeton University Press 2015.

BELl Daniel: The Coming of Post-industrial Society: A Venture In Social Forecasting, New York: Basic Books 1973.

BERNSTEIN Maryer: Regulating Business by Independent Commissions, New Jersey: Princeton University Press 2015.

BIEŚ-SROKosz Paulina: Agencje rządowe jako szczególne podmioty administracji publicznej, Warszawa: C.K. Beck 2020

Blokker Paul: Populist Constitutionalism, [in:] Routledge Handbook of Global Populism, ed. Carlos de la Torre, London: Routledge 2018, pp. 129-144.

Bovens Mark, WiLle Anchrit: Diploma Democracy: The Rise of Political Meritocracy, Oxford: Oxford University Press 2018.

BREger Marshal Jordan, EdLes Gary J.: Independent Agencies in The United States: Law, Structure and Politics, Oxford: Oxford University Press 2015.

BREGER Marshall J., EDLES Gary J.: Established by practice: the theory and operation of Independent Federal Agencies», “Administrative Law Review” Vol. 52, 2000, No. 4, pp. 1111-1294. 
Bull Reeve T.: Making The Administrative State "Safe For Democracy": A Theoretical And Practical Analysis Of Citizen Participation In Agency Decisionmaking, "Administrative Law Review" Vol. 65, 2013, No. 3, pp. 611-664.

Burnham James: The Managerial Revolution: What is Happening in the World, New York: John Day Co. 1941.

Busuioc Elena Madelina: European agencies: Law and practices of accountability, Oxford: Oxford University Press 2013.

Chiтi Edoardo: European Agencies' Rulemaking: Powers, Procedures and Assessment, "European Law Journal" Vol. 19, 2013, No. 1, pp. 93-110.

Christensen Tom, LÆgreid Per: Autonomy and regulation: Coping with agencies in the modern state. Cheltenham: Edward Elgar Pub 2006.

Croley Steven: Regulation and Public Interests: The Possibility of Good Regulatory Government, New Jersey: Princeton University Press 2008.

Custos Dominique: The Rulemaking Power of Independent Regulatory Agencies, "The American Journal of Comparative Law" Vol. 54, 2006, pp. 615-639.

DeMuth Christopher: Can the Administrative State Be Tamed?, "Journal of Legal Analysis" Vol. 8, 2016, No. 1, pp. 121-190.

DERESIEWICZ William: Excellent Sheep: The Miseducation of the American Elite and the Way to a Meaningful Life, New York: Free Press 2014.

Devins Noel, Lewis David: Not-So Independent Agencies: Party Polarization and the Limits of Institutional Design, “Boston University Law Review” Vol. 88, 2008, pp. 459-498.

DoMAŃSKI Henryk: Struktura społeczna: wydanie nowe, t. I, Warszawa: Wydawnictwo Naukowe Scholar 2007.

FISHER Louis: Legislative Veto: Invalidated it survives, "Law and Contemporary Problems" Vol. 56, 1993, pp. 273-292.

Galbraith John Kenneth: The New Industrial State, Boston: Houghton Mifflin Harcourt 1967.

GiDDENS Anthony: Socjologia, Warszawa: PWN 2004.

GIFFORD Daniel J.: The New Deal Regulatory Model: A History of Criticisms and Refinements, "Minnesota Law Review" Vol. 68, 1983, pp. 299-332.

GILARDi Fabritzio, MagGeTti Martino: The independence of regulatory authorities, [in:] Handbook on the politics of regulation, ed. David Levi-Faur, Cheltenham: Edward Elgar 2011, pp. 201-214.

GiLmORE Grant: The Ages of American Law, New Haven-London: Yale University Press 1977.

GROENLEER Martijin: The autonomy of European Union agencies: A comparative study of institutional development, Delft: Eburon Uitgeverij BV 2009.

Guy B. Peters: The United States of America, [in:] Koen Verhoest, Sandra Van Thiel, Geert Bouckaert, Per LÆgerid, Government Agencies. Practice and Lessons from 30 Countries, New York: Palgrave Macmillan 2012.

Hargrove Erwin C., Glidewell John C.: Impossible Jobs In Public Management, Lawrence: University Press of Kansas 1990.

HAYES Chris: Twilight of the Elites: America after Meritocracy, New York: Broadway Books, 2012. IONESCU Ghita: The Political Thought of Saint-Simon, Oxford: Oxford University Press 1976.

JASIECKI Krzysztof: Zasady merytokratyczne w polityce państwa - wzloty i upadki, „Studia z Polityki Publicznej” Vol. 11, 2016, No. 3, pp. 9-40. 
JoHnson Stephen: Junking the "Junk Science" Law: Reforming the Information Quality Act, "Adminstrative Law Review" Vol. 58, 2006, pp. 37-83.

KagAn Robert A.: Adversarial Legalism: The American Way Of Law, Cambridge-London: Harvard University Press 2001.

Kennedy Duncan: The Political Stakes in "Merely Technical" Issues of Contract Law, "European Review of Private Law" Vol. 10, 2001, No. 1, pp. 7-28.

Kerwin Cornelius M., Furlong Scott R.: Rulemaking: How Government Agencies Write Law and Make Policy, fifth edition, Washington: CQ Press 2018.

KeTt Joseph F.: Merit: The History of a Founding Ideal From the American Revolution to the Twenty-First Century, New York: Cornell University Press 2012.

KIM Chang-Hee, CHOI Yong-Beom: How Meritocracy is Defined Today?: Contemporary Aspects of Meritocracy, "Economics and Sociology" Vol. 10, 2017, No. 1, pp. 112-121.

KREHER Alexander: Agencies in the European Community - a step towards administrative integration in Europe, ,Journal of European Public Policy”, No. 4, 1997, pp. 225-245.

KURCZEWSKA Joanna: Technokraci i ich świat społeczny, Warszawa: Wydawnictwo ISiF PAN 1997.

ŁАКомY Jakub: Polityczność (teorii) wykładni prawa. Perspektywa neopragmatyzmu Stanleya Fisha, „Archiwum Filozofii Prawa i Filozofii Społecznej” 2018, No. 3(18), pp. 24-37.

LAMPERT Khen: Meritocratic Education and Social Worthlessness, London: Palgrave-Macmillan 2012.

LIPSEY David: The Meretriciousness of Meritocracy, “The Political Quarterly” Vol. 85, 2014, No. 1, pp. 37-42.

LitTeR Jo: Against Meritocracy. Culture, power and myths of mobility, London-New York: Routledge 2018.

LubBERs Jeffrey: Guide to Federal Agency Rulemaking, Chicago: American Bar Association 2006.

MAgGetTI Martino: Legitimacy and Accountability of Independent Regulatory Agencies: A Critical Review, "Living Reviews in Democracy" 2010, No. 2, pp. 1-9.

MAŃKo Rafał: W stronę krytycznej filozofii orzekania. Polityczność, etyka, legitymizacja, Łódź: Wydawnictwo Uniwersytetu Łódzkiego 2018.

MANUEl Frank: The New World of Henri Saint-Simon, Cambridge, Mass., 1956.

Markowski Radosław: Populism and Nationalism in CEE: Two of a Perfect Pair?, [in:] When Populism meet Nationalism. Reflections of Parties in Power, ed. Alberto Martinelli, Milan: Ledizioni Ledi Publishing 2018, pp. 71-94.

MARShall Gordon, SwIFT Adam: Meritocratic Equality of Opportunity: Economic Efficiency, Social Justice, or Both?, "Policy Studies" 1997, No. 18, pp. 35-48.

Martin David A.: The Legislative Veto and the Responsible Exercise of Congressional Power, "Virginia Law Review" Vol. 68, 1982, No. 2, pp. 253-302.

Mashaw Jerry L.: Reasoned Administration and Democratic Legitimacy: How Administrative Law Supports Democratic Government, Cambridge: Cambridge University Press 2018.

McGarity Thomas O.: Some Thoughts on "Deossifying" the Rulemaking Process, "Duke Law Review" Vol. 41, 1992, pp. 1385-1462.

MCGARITY Thomas O.: The Courts and the Ossification of Rulemaking: A Response to Professor Seidenfeld, “Texas Law Review” Vol. 75, 1996-1997, pp. 525-558.

Meritocracy and Economic Inequality, eds. Kenneth J. Arrow, Samuel Bowles, Steaven N. Durlauf, New Jersey: Princeton University Press 2000. 
MerRiLl Thomas W., WatTs Katryn T.: Agency Rules with the Force of Law: The Original Convention, "Harvard Law Review" Vol. 116, 2002, No. 2, pp. 467-592.

Miller Geoffrey P.: Independent Agencies, “The Supreme Court Review” 1986, pp. 41-97.

Modernizacja refleksyjna. Polityka, tradycja i estetyka w porządku społecznym nowoczesności, eds. Ulrich Beck, Anthony Giddens, Scott Lash, Warszawa: PWN 2009.

MoufFe Chantal: Polityczność, Warszawa: Wydawnictwo Krytyki Politycznej 2008.

Mouk Yascha: The People vs. Democracy. Why Our Freedom in in Danger and How to Save it?, Cambridge: Harvard University Press 2018.

MüLLER Jan-Werner: What is Populism?, Philadelphia: University of Pennsylvania Press 2016.

Mulligan Thomas: Justice and Meritocratic State, London: Routledge 2019.

QuiRK Paul J.: Industry influence in Federal Regulatory Agencies, New Jersey: Princeton University Press 2014.

RASO Connor: Agency Avoidance of Rulemaking Procedures, “Administrative Law Review” Vol. 67, 2015, No. 1, pp. 61-132.

ReISs, Dorit Rubinstein: Account Me In: Agencies in Quest of Accountability, „Journal of Law and Policy" Vol. 19, 2011, No. 2, pp. 611-681.

Rittberger Berthold, Wonka Arndt: Agency Governance in the EU, London: Routledge 2013.

RORY O'Connell: Guardians of the Constitution: Unconstitutional Constitutional Norms, "Journal of Civil Liberties" 1999, No. 4, pp. 48-75.

SABATIER Paul: Social Movements and Regulatory Agencies: Toward a More Adequate - and Less Pessimistic -Theory of "Clientele Capture", "Policy Sciences" Vol. 6, 1975, pp. 301-342.

SCHOLten Miroslava: Democratic Input Legitimacy of IRAs:Proposing an Assessment Framework. "Utrecht Law Review" Vol. 11, 2015, No. 2, pp. 64-77.

SEALY Ruth: Changing Perceptions of Meritocracy in Senior Women's Careers, "Gender in Management: An International Journal" Vol. 25, 2010, No. 3, pp. 184-197.

Stone Richard David: The Interstate Commerce Commission and the railroad industry: a history of regulatory policy, New York: Praeger 1991.

Sulikowski Adam, MAŃKO Rafał, ŁAKOMY Jakub: Polityczność prawa i ogólnej refleksji nad prawem: zagadnienia ogólne, „Archiwum Filozofii Prawa i Filozofii Społecznej” 2018, No. 3(18), pp. 5-9.

TAGGART Paul: Populism, Buckingham: Open University Press 2000.

Veblen Thorstein: The Engeneers and The Price System, [in:] What Veblen Thaught: Selections from the Writings of Thorstein Veblen, New York: Martino Fine Books 2012.

Williams Marcus D.: Judicial Review: The Guardian of Civil Liberties and Civil Rights, “George Mason University Civil Rights Law Journal” 1990, No. 1, p. 277.

Young Michael: The Rise of Meritocracy: 1870-2033, Harmondworth: Pinguin 1958. 


\title{
MERITOCRATIC JUSTIFICATION IN RULEMAKING \\ AND ITS CRITICISM BASED ON THE EXAMPLE \\ OF AMERICAN REGULATORY AGENCIES
}

\begin{abstract}
Summary
Mertitocracy, in the intention of the author of this concept Michael Young, meant entrusting the exercise of power over specific areas of social life to people with appropriate skills and competence. The implementation of meritocratic assumptions in social reality was to create a system where experts were to play a key role in managing social life. This postulate also referred to creating regulations for selected areas of social life, which should be entrusted to specialized, professional entities. The Author discusses the importance and role of meritocratic justification for legislation on the example of US independent regulatory agencies. This justification has a twofold role: 1) as a factor legitimizing the shape of the introduced regulations and 2) as a camouflage for the implementation of the interests of the agencies themselves or of specific pressure groups or group of interests.
\end{abstract}

Key words: meritocracy; justification; regulatory agencies; rulemaking; political

\section{UZASADNIENIE MERYTOKRATYCZNE W PRAWOTWÓRSTWIE I JEGO KRYTYKA NA PRZYKŁADZIE DZIAŁALNOŚCI AMERYKAŃSKICH AGENCJI RZĄDOWYCH}

\section{Streszczenie}

Mertytokracja, w zamyśle autora tego pojęcia Michaela Younga, oznaczała powierzenie sprawowania władzy nad określonymi obszarami życia społecznego osobom posiadającym odpowiednie do tego umiejętności. Skutkiem implementacji założeń merytokratycznych miało być stworzenie systemu, gdzie kluczową rolę w zarządzaniu życiem społecznym pełnić mieli eksperci. Postulat ten odnosił się także do tworzenia regulacji wybranych dziedzin życia społecznego, co powinno zostać powierzone wyspecjalizowanym, profesjonalnym podmiotom. Autor omawia znaczenie i rolę uzasadnienia merytokratycznego dla prawodawstwa na przykładzie amerykańskich agencji regulacyjnych. Uzasadnienie to ma dwojakie znaczenie: 1) jako czynnik legitymizujący kształt wprowadzanych przepisów oraz 2) jako kamuflaż dla realizacji interesów samych agencji czy też określonych grup nacisku czy interesów.

Słowa kluczowe: merytokracja; uzasadnienie; agencje regulacyjne; prawotwórstwo; polityczność 